2. Ганич Д.І., Олійник І.С. Словник лінгвістичних термінів. Київ: Вища школа, 1985. 360 с.

3. Деякі питання документування управлінської діяльності: Постанова КМУ від 17 січня 2018 р. № 55 / Верховна Рада України. URL: https://zakon.rada.gov.ua/laws/show/55-2018-\%D0\%BF\#top

4. Карпенко О.Ю. Про літературну ономастику та ії функціональне навантаження. Записки з ономастики. 2000. Вип. 4. С. 68-74.

5. Лотте Д.С. Вопросы заимствования и упорядочения иноязычных терминов и терминоэлементов. Москва: Наука, 1982. 149 с.

6. Сингаївська Г.В. Власне ім'я в лексико-семантичній системі мови. Проблеми семантики, прагматики та когнітивної лінгвістики. Вип. 24. 2013. С. 365-373.

7. Словник української мови: в 11 т. / редкол.: І.К. Білодід (голова). Київ: Наук. думка, 1970-1980. Т. 1: А-В. 1970. 799 с.

8. Суперанская А.В. Что такое топонимика. Москва, 1985. 185 с.

9. Фонякова О.И. Имя собственное в художественном тексте. Ленинград, 1990. 103 с.

10. Юшак В.М. Власні імена як об'єкт лінгвістичного аналізу. Наукові записки. Серія “Філологічна”. Вип. 24. 2012. С. 303-305.

DOI https://doi.org/10.30525/978-9934-588-90-7-14

\title{
МЕТОДОЛОГІЙНІ ДОМІНАНТИ АНАЛІЗУ ІДІОДИСКУРСУ Ф. М. ДОСТОєВСЬКОГО
}

\author{
Шепель Ю. О. \\ доктор філологічних наук, професор, \\ академік Національної академії наук ВО Украӥни, \\ професор кафедри перекладу та лінгвістичної підготовки іноземиів \\ Дніпровський національний університет імені Олеся Гончара \\ м. Дніпро, Украӥна
}

Концепція мовної особистості, як будь-яка інша, вимагає, з одного боку, своєї практичної реалізації, з іншого, щоб отримати розвиток, а не слугувати семантично спустошеною догмою, може і повинна бути використана в самих різних наукових областях, збагачуватися новим матеріалом. Сам автор цієї концепції, Ю. М. Караулов, визначає три можливі методи дослідження мовної особистості - за допомогою асоціативного експерименту, за допомогою вивчення дискурсу персонажа літе- 
ратурного твору і через укладання словника, але словника особливого типу, з певним набором лексикографічних параметрів [2].

Мовну особистість розглядаємо в «ії трьох іпостасях: 1) ідіоглосарії (словах, що характеризують особливості авторського стилю, ідіоглосах), 2) тезаурусі (ідіографічній класифікації ідіоглос) і 3) ейдосі (авторських ідеях, що знайшли відображення в багатопараметровому лексикографічному описі ідіоглос), що певним чином корелює 3 традиційно виокремлюваними рівнями структури мовної особистості - вербальнограматичним, когнітивним (або рівнем мовної картини світу) i мотиваційно-прагматичним.

У роботі вжито основні загальнонаукові методи спостереження, порівняння та опису, що спрямовані на узагальнення отриманих результатів, аналіз й інтерпретацію даних, їх систематизацію та класифікацію.

У якості методологійної бази використано теоретичні положення, що викладені в роботах, присвячених загальній теорії стилю, імпліцитності й ідіостилю, в яких описане коло основних понять, представлено різні підходи до вивчення індивідуального стилю того чи того автора.

Індивідуальний стан мови в наш час має для дослідників особливий інтерес, у зв'язку з чим поняття ідіостилю як мовного засобу реалізації ідіолектної особистості $[1 ; 2]$ перебуває у центрі наукового інтересу лінгвістів через усунення категорії соціалістичного реалізму, визнання багатогранності творчого процесу, авторської стилістики і т. ін. Увага науковців зосередилася на питанні більш грунтовного дослідження індивідуальних мовних рис творчої особистості. Безумовно, інтерес до ідіолектної індивідуальності в мові цілком закономірний, тому що ідіолектна особистість реалізується на тлі картини світи і переломлює в собі і через себе як номінації конкретного тимчасового (суспільно-політичного, культурного, духовного) значення, так і загальномовного рівня.

Питання ідіостилю набуло комплексного характеру, відповідно до чого аналіз ідіостилю Ф. М. Достоєвського вимагає багаторівневого підходу. На цей час лінгвісти пропонують розглядати ідіолектні особистості за двома ідіолектними типами:

- стандартна мовна особистість, яка відображає усереднену норму літературно обробленої мови;

- нестандартна мовна особистість, яка характеризується відхиленням від усталених міжособистісних і міжкультурних комунікативних норм.

Отак, висновки про особливості мовної особистості можна здійснити тільки на основі конкретного лінгвістичного аналізу створених нею текстів. 
Сучасна лінгвістика, орієнтуючись на когнітивні потреби людини, перейшла від дослідження тексту до аналізу дискурсу, де важливими постають психологічні, екстралінгвістичні та когнітивні знання людини. Процес читання наразі розглядають як діалог письменника та читача.

За дискурс приймають складне комунікативне явище, яке містить окрім тексту екстралінгвістичні фактори, які потрібні саме для повного та правильного розуміння тексту.

Дискурс вбирає все розмаїття мови, ментальність та національнокультірні особливості комунікативної ситуації.

Основним проявом імпліцитності в дискурсі є іï когнітивний статус, орієнтування на фонові знання реципієнта та прихований емоційнопсихологічний вплив на читача.

За дискурс Ф. М. Достоєвського ми сприймаємо характер викладення творів письменника та його відмінні мовні особливості. Ідіодискурс комунікативно-художній простір автора та читача, який в сукупності та взаємодії усіх своїх аспектів, утворює цілісне комунікативне середовище, в яке поринають усі, хто бере участь у процесі комунікативної діяльності. У такому комунікативно-художньому просторі постає ідіостиль індивідуально-авторські особливості світосприйняття та текстової діяльності, які віддзеркалюються в тексті як формі комунікації, включно 3 організацією діалогу з читачем.

Художній текст вирізняється неповторною авторської індивідуальністю. Отож ідіолектна особистість демонструє унікальну майстерню індивідуального стану мови, а це дозволяє нам говорити про авторський ідіостиль. На цей час ми можемо говорити про те, що поняття «ідіостиль» ще знаходиться в стані наукового становлення, тому цілком зрозумілим $є$ існування різних дефініцій ідіостилю. Цілком можна погодитися 3 думкою лінгвістів, що ідіостиль - це інваріантний особистісний сенс, що має під собою концептуальну основу.

Стиль автора позначається в стилі художнього твору. Він багато в чому визначає комунікативно й естетично обумовлені принципи організації тексту, відбір і сполучуваність мовних засобів, вибір стилістичних прийомів. До поняття ідіостилю залучаємо також, на тлі загальномовної комунікативної структури, характер асоціативно-смислового розгортання тексту, що визначає його структуру, прагматику і семантику. Отож ідіостиль реалізує мовну особистість автора, його картину світу за допомогою індивідуального використання мови в естетичній сфері.

Змістова риса авторського ідіостилю Ф. М. Достоєвського пов'язана 3 релігійними та історико-філософськими поглядами письменника. Ідеї 
милосердя, вірного напрямку заблукалої душі, спокуси та покаяння перебувають у центрі будь-якого роману письменника.

Для творчої манери Ф. М. Достоєвського характерне глибоке проникнення в сутність описуваного автором явища, його осмислення та детальне зображення. Найбільшого впливу на Ф. М. Достоєвського мала Біблія, тому біблійні алюзії та цитати прослідковуються в ідіодискурсі письменника. Спостерігаємо також фольклорні, літературні, міфічні запозичення в романах письменника Мовні особливості ідіодискурсу Ф. М. Достоєвського примічаємо також на рівні синтаксису, а саме використання ускладнених конструкцій, переважно трикомпонентних. Синтаксична модель мови представлена великою кількістю повторів, символів, інверсій.

Просторово-часові відношення у тексті романів витримано автором за принципом хронотопу.

\section{Література:}

1. Виноградов В.В. Проблема авторства и теория стилей. Москва : Художественная литература, 1961.614 с.

2. Караулов Ю. Н. Русский язык и языковая личность. Москва : Изд-во ЛКИ, 2010. 264 с. 